\title{
Children's literature in Kenya: a mirror of Kenyan culture?
}

\author{
Mikhail D. Gromov
}

\begin{abstract}
The article is based on the assumption that the present state of writing for children in Kenya could in fact be reflecting the current condition of the entire Kenyan culture, particularly the culture of letters in the country. Using as a reference point the well-known book on Kenyan children's literature written in 1980s by Asenath Odaga, the author indicates the achievements made by Kenyan children's literature within the last two decades (e.g., efforts being made by both international and local publishers to increase the number of books and variety of titles suitable for different age groups), as well as problems still existing in the field (one of the major ones being the shortage of books in indigenous languages, with possible exception of Kiswahili). The author states that these problems could be applied to Kenyan writing culture in general. The article also proposes some guidelines towards the improvement of the current situation.
\end{abstract}

\section{Introduction}

Twenty-one years ago, a prominent Kenyan writer and scholar of children's literature Asenath Bole Odaga published a book entitled Literature for Children and Young People in Kenya. Leaving aside the fact that up to this day the book seems to remain the only monographic study dedicated to literature for young readers in Kenya, it covers, in a very detailed and exhaustive manner, insights on children's literature in Kenya from the 1960s to early1980s. Let us quote some main points from Odaga's work which illustrates the basic challenges that faced children's literature in Kenya in the past decades:

The post-independence books written by Africans have sought to make the African aware of what he lost during the colonial period. The books are an attempt to give the children clear scope and ideas about their world, by depicting modes of behaviour familiar to the communities that form their society. The writers are trying to achieve this through literature that treats simple everyday events, involving activities on which the children and youth often engage. The African child of today is lucky in that he has become a member of the global village and can share much with other children from other parts and distantly situated homes. He can share in all manner of activities with them through watching television and films. But the African child must also be able to contribute something to that global village, a contribution which is very much overdue. And whatever the Kenyan child gives, would only be interesting to the other children if it is fresh, African and local.

If the English child sings about mother Hubard, the Kenyan child does not have to sing the same Hubard immediately he leaves the cradle; he should be able first to sing a different song about his experience as an African and then later on sing and learn about mother Hubard to enrich and widen his knowledge of the world. 


\section{Suitability of children's books}

Some of the books that have developed since independence tend to be universal in nature. The setting can be anywhere in any part of the world where the same conditions are prevalent. There is no harm in this, but there is need for books to have positive settings that depict experiences of a particular people. It is only fair therefore that literature for children and youth should first and foremost be about situations which are local and familiar to them before fanning out to the universal.

In the last ten years or so, there are writers who have produced some works of literature which are suitable for Kenyan children and young people. The works are in the form of short stories, novels and novelettes, drama and poetry, and folk tales translated into English. The themes and topics the writers have treated are as varied as the works themselves. In some of the books, the writers have treated contemporary issues relevant to post-colonial era. They have also evoked conflicts created by interaction and friction between the western cultural Christian values, Islamic and the African traditional values relating closely to social set ups and conventions (3738).

Further in the book Odaga analyses some children's books by Kenyan writers who, in her opinion, serve the above-mentioned tasks (among these she also mentions 'fight for cultural freedom'). The list of books analysed includes some well-known texts, such as The Children of the Forest by Joel Makumi (1968), Onyango's Triumph by Leo Odera Omolo (1968), The Eighth Wife by Miriam Khamadi Were (1972). Moreover, the writer reminds that 'the books that have been mentioned... are by no means the only ones suitable for children and young people. There are others as well, but due to the nature of this study, we could only examine a limited number (61). However, it is worth mentioning that the number of children's books written by Kenyan writers by the time the bulk of Odaga's book was finished (the author confesses in the Preface that most of the book was completed in the years 1971-74), was limited by itself - barely several dozens of titles were available by the year 1985, when Odaga's research was published in a book form. Acknowledging this, the writer admits that there is still much to be done. Kenyan literature for children faces much more grandiose tasks, and outlines some of them. Here I quote selectively the writer's observations about the tasks for the future (stress is mine - M.G.):

The Ministry [of Education] could assist by setting up a research centre for local literature, with researchers whose main job would be to find out the needs of the schools in the country and try to have or to prepare suitable material to bridge the gap. The participation and contribution of curriculum development centre, Kenya Institute of Education would add to the usefulness of such a project.

It is also important that the government should encourage local publishers and writers to produce more books local and familiar themes which would prove to be more appropriate to the needs of the people. 


\section{Indigenous languages and publication of children's literature}

While it is a fact that Kiswahili is spoken by a good cross section of the population, there are many people in Kenya today who through no faults of their own can hardly speak a word of Kiswahili...

To neglect the local languages of the various Kenyan nationals is in fact comparable to ignoring and causing psychological harm to those very people. ...A language is a carrier of values and some of these values are in fact valuable heritage which must be preserved for posterity. The production of more literature for children in these indigenous languages must therefore be encouraged. Nonetheless, so long as the publishers of books for children continue to be overseas based, controlled by long invisible strings; not much meaningful change can be expected in the near future.

The [two] national universities, as the highest seats of learning must take a lead in developing local literature... It would also be desirable for the Ministry of Education to establish a literary association... It could do much through encouraging young and up-coming writers... (65-67).

Twenty-one years have passed since the time Asenath Odaga published her study. Were there any changes (at least-visible) in the situation with children's literature in Kenya?

It seems that considerable change has been made at least to one of the main issues - the encouragement of local publishers. As if answering Odaga's lament about 'publishers of books for children continue to be overseas-based', the latest reference book on African writing - internationally published Companion to African Literatures (2000) - triumphantly states that 'for a variety of reasons, African states administrators have encouraged the development of indigenous publishing houses... Since 1975 more than seventy new indigenous book publishing concerns have been established in sub-Saharan Africa. In Kenya alone here have been eleven such initiatives, including East African Educational Publishers, which resulted from the indigenization of Heinemann in 1992, and Longhorn Kenya, which emerged in 1994 through the localization of Longman' (66).

It should be noted that the due credit must still be paid to international printing giants such as Macmillan, which continues to serve Kenyan children with carefully and skilfully developed reading schemes. Currently, Macmillan offers the younger readership in Kenya such series as Reading Worlds (Everyday, Discovery, Imaginary - each for 7 levels, 21 series in total, authors from Africa and outside); Ready Go - for nursery and pre-school, 28 titles all in all; Hop, Step, Jump - 60 titles; Mactracks - 9-14 years, 50 titles; Stories to Remember - adaptations of world classics for juvenile readers (no African writers); Scientific - earth, health, AIDS; Bible stories - for 4-8 years; Guided Readers - adaptations of African classics for children (Head, Achebe, Amadi, Abrahams, Ngugi); Today's Children - stories about young refugees; Young Lives - young women in Africa; Wild Things - wild animals of African continent; and their masterpiece for adolescent readers - Pacesetters 
(more than 140 titles) and its more recent extension - Trendsetters (featuring such renowned African authors as Barbara Kimenye, Rosina Umelo and others).

However, local publishing houses in Kenya are successfully trying to keep the pace. East African Educational Publishers, leading publishing house in the country, provides the young readers with such series as Sunbird Readers (10 titles) and Sparrow Readers (20 titles) for younger children, Junior Readers (50 titles - recruited some of Africa's best-known writers for this series, including Ekwensi, Achebe, Charles Mungoshi, and Ngugi); Makers of Kenyan History - 15 biographies of such people as Mwana Kupona, Nabongo Mumia, Alibhai Jevanjee, Dedan Kimathi, Jomo Kenyatta, Tom Mboya, Oginga Odinga, Mwai Kibaki, and others; Great Scientists - 10 biographies of such people as Marie Curie, the Wright brothers, Albert Einstein, Charles Darwin, Isaac Newton, Galileo Galilei, Thomas Edison, Alexander Bell, Archimedes, Alfred Nobel; Secondary Readers - about 20 titles, among them Cyprian Ekwensi, Barbara Kimenye, and others).

Kenya Literature Bureau publishes Early Childhood Education Story (7 titles), having the total of 35 titles in children's literature section; Longhorn produces such series as Weaverbird for 10-16 years (13 titles), Jumbo Junior (4-11 years -7 titles), Poetry for Schools (3 titles), Puzzle Cracker (11-15 years - 4 titles), Longhorn Reading Scheme (3-8 years - 11 titles, 9-12 years - 5 titles), Keynote Primary English Reading Scheme - 23 titles. Phoenix Publishers has initiated the successful Phoenix Young Readers Library (55 titles).

Odaga's lament that Kiswahili, in spite of its real status of the main language of the country, was in fact known poorly to many Kenyans, is also currently met by the changes for the better - Kiswahili has been introduced as a compulsory subject at schools, the choice and quality of textbooks deserve every praise, and the situation with children's in Kiswahili literature seems to be undergoing similarly positive alterations. Kenyan publishers support the spread of language by increasing the number of children's titles in Kiswahili. EAEP produces such series as Visa na Mikasa - 10 titles for primary school by the well-known writer Zacharia Zani; Paukwa Pakawa - adaptations of folktales; Vitabu vya Nyota - 15 titles, mainly tales; Vitabu vya Sayari - 15 titles of the same kind for slightly older audience. Longhorn gives out Hadithi za Kusisimua series for junior teenagers (8 titles, among them such writers as Leo Omolo and John Simbamwene), Hekaya za Kuburudisha - 6 titles (among them translations of Stevenson and Haggard), Michezo ya Kuigiza (2 titles), Mfululizo wa Masomo (for young children) - 10 titles. Phoenix Kiswahili Readers includes 12 titles, Kenya Literature Bureau has 11 Swahili titles in children's section. Oxford University Press prints the series titled Mradi wa Kusoma Kiswahili Sanifu - 16 titles.

A prominent role is played by recently emerged printers, such as Sasa Sema and Focus Publishers, which provide children's series both in Swahili and English, - not mentioning smaller publishing houses like Pauline Publishers, Uzima Press, etc. So the overall picture appears to be quite a positive one. But, in real sense, is the state of things that excellent? 
The largest producer of children's literature in Kenyan market is, in fact, not Kenyan - this position is still occupied by international publishing monster Macmillan (it also plays the major part in popularising creative writing from other African countries). Scanning through the catalogues of Kenyan publishers, one will easily see, that the bulk of books are written in the foreign language (over 250 titles in English against 100 Kiswahili titles). What about other local languages?

Alas! The situation with local languages obviously has not improved. It could be observed that in 1960s and 1970s Kenyan publishers (especially KLB) were paying much more attention to publication in indigenous languages. Currently, among the publishers listed above only EAEP has 5 (!) titles in indigenous languages in its catalogue - the catalogues of the others seems to be absolutely 'clear' of such 'unsellable commodities'. But - how unsellable are the indigenous books, and if so what is the reason?

\section{Predispositions with respect to books in local languages}

We conducted some interviews with a few potential customers and sellers of children's literature, all of them being native or naturalised Kenyans ${ }^{*}$, dwelling in Nairobi as well as some large provincial towns. I hope these quotations will be helpful to illustrate my assumptions about the current state of children's literature in Kenya and - being reflected in it - the current state of Kenyan indigenous cultures.

A young lady, a student at USIU, after repeated attempts managed to find only one book in her native Kikamba - the book of religious instruction, printed, according to her, "on sort of recycled paper". She comments: "If it were up to me, I would pick a book in the English or Swahili language, which I am more fluent in and faster in reading. I am pro-vernacular and I believe there are many people who can read Kikamba fluently, therefore, the books should still be printed and translated for them".

Another student of the same university, a young mother, affirms that her two children can write and speak Kiswahili and Kikuyu fluently, and she is very proud of that - but it was due only to her own effort; there were no other opportunities - books inclusive - to educate them in their mother tongue.

A young mother, studying at the same university, being of Ethiopian origin, but married to a Kenyan, states that, while facing a challenging task to educate her children in the two of their mother tongues, she found it easier to find books in her native Amharic - bringing them from Ethiopia and even buying them here - than to find anything in her husband's native tongue.

\footnotetext{
* The interviews quoted here were conducted by Ms. Heer Raja, a graduate student of USIU, as part of her work for the course of literature, and are reproduced with her kind permission.
} 
In the above mentioned study Asenath Odaga complained that 'there are still some parents and teachers alike who... would condemn locally produced books as being poor and low in quality' (69). But who has currently at least tried to make a change to this opinion? The heroic attempts of Ngugi to establish the children's series in Kikuyu by publishing in 1986 two pieces of fiction - Njamba Nene and the Flying Bus and Njamba Nene's Pistol (both later translated into English by Wangui wa Goro) - remains a lone voice in the desert; other attempts to publish in local languages, made by Odaga, Maillu and some other writers, are dismal.

Richard, a shop assistant in Text Book Centre in Westlands, confessed that they stopped keeping children's books in local languages (except Swahili) in late 2005. This was due to the fact that they "do not sell".

It probably would not have been worthwhile to make such a 'fuss' about local books, if it did not reflect the overall situation with Kenyan local cultures. "Kenyan local languages are dying" - that is the opinion that is heard more and more often. Remembering that language is the principal bearer of a culture - does it not mean that the cultures of Kenyan communities, even the major one, are likely to vanish, giving way to mixed 'English-cum-Sheng' culture of unknown values and orientations?

No one - and me the least - would dare say that local Kenyan cultures will perish in the nearest future. Fortunately, they are alive, they are practiced by the people, and they are passed to the children. But they are passed mainly by the word of mouth, and the languages from which these words are taken are neglected, and that is the first symptom causing anxiety. How long will this last? At least two generations of urban Kenyans currently are using their mother tongues mainly while visiting their relatives in rural areas. Bearing in mind the tempo of urbanisation in the country - for how long will the rural homesteads manage to preserve their functions of sole bearers of local cultures? Or could these cultures be passed to the young ones by 'cultural nights' at Carnivore ${ }^{1}$, or similar cosmetic undertakings?

\section{Language as a tool for preservation of culture}

The question is: Is there a need to preserve these cultures? Yes, the need is there, and I hope that the above-quoted interviews prove it. People are proud of their cultures, they want their children to maintain them - and, taking into account the rapidly changing social conditions in the country, the principal means to do this is conscious and centralised preservation and development of the local languages. Language conserves the culture; language preserves and passes the culture's values and history. And the best way to acquaint people with these

${ }^{1}$ The Carnivore restaurant regularly hosts since the late 1990s dinners and dances from the various ethnic communities in Kenya. 
values and history of their culture is to provide them with appropriate language environment in the childhood - the time when a person is most sensitive and has time, necessity and desire to absorb these things.

Again, Kiswahili and English are absolutely essential - but they will be acquired anyway, in secondary and high school, not mentioning the university. Green years - that is when a person should absorb the culture of his people via language - should provide the young readers with many good books that highlight their culture and language. Yes, we say proudly that current children's books acquaint the young readers more thoroughly with national history; at least two publishing houses currently print continued series of biographies of outstanding figures in Kenyan history. Definitely that is good; but how good is it when a Kikuyu child reads - for the first time - about Dedan Kimathi and Jomo Kenyatta in English? And when a Luo child meets Lwanda Magere and Gor Mahia in the same language? No one denies the importance of English as an international language - but should it be promoted to the detriment of indigenous languages?

Various solutions could be offered to this situation; a young teacher, working at My School Montessori, said that, before she went to primary school in Kiambu District, all the subjects in Standard 1-3 were taught in Kikuyu, and she found it very useful. But, according to her, "after 1990 most schools stopped that system". (Even the Swahili syllabus, as she said, did not include any children's books; instead they read the translation of Orwell's Animal Farm - a good choice for Swahili literature! - and detective story Kisima cha Giningi by Tanzanian writer Mohamed Said Abdulla, written around 1960).

Children's drama has universally been recognised as a powerful tool for distributing both the appreciation of literature and general enculturation. How many plays for children do we have here in Kenya? School drama festivals annually present at least dozens of worthwhile works produced by the children and their teachers - do many of them get polished and published?

A couple of years ago, I observed how the children from various primary schools were brought in buses to the National Theatre in Nairobi to be treated to Aminata by Francis Imbuga. No doubt, it is a wonderful play - but how primed were the primary students to grasp the issues of female emancipation, greed for power, land inheritance and, God forbid, vasectomy? Would it not have been more appropriate to give them something more 'age-relevant'?

Kithaka wa Mberia in the first issue of Nairobi Journal of Literature wrote about the importance of the use of Kiswahili and other indigenous Kenyan languages in performing arts, providing the readers with detailed arguments about the necessity of making these languages part and parcel of Kenyan theatrical scene. I quote some of them:

The first argument concerns the importance of indigenous languages in national development. In some quarters, these languages are seen as cultural relics, which are irrelevant for national development. Nothing could be further from the truth. Indigenous languages are a national asset not only at the 
cultural level but also at the economic level. They are an economic resource base that can and should be tapped for the economic well-being of the country... Using these languages as media for our theatre will contribute towards their vibrancy and growth...

We have many burning issues in our society, which we need to address... Drama can be a powerful tool for discussing these issues. However, when plays are written in English, many Kenyans cannot join in..., they are shut out by the language barrier...

The relationship between drama on the one hand and Kiswahili and other indigenous languages on the other should be a symbiotic one. Drama should serve as a medium through which these languages can be promoted. In turn, these languages should help to promote drama in the general population (63-65).

Even the most frequently expressed doubt that "there will be no audience for the play in a local tongue" is aptly refuted. For example, in the same article, Wa Mberia posits that "plays in local languages can pull big crowds" (65-66). If even an adult audience, whose theatre-going habits are already hampered by their upbringing, can crowd a performance of a 'native tongue' play, imagine how overwhelming could be children's reaction to a good - carefully chosen and masterfully staged - story in their mother tongue! And what can be more beneficial to the general and thorough acquaintance of a child with the culture of his own community?

One of Odaga's above-quoted lamentations concerned the participation of governmental institutions in preparation and distribution of children's books. Although the dream of a 'research centre... whose main job would be to find out the needs of the schools in the country and try to have or to prepare suitable material to bridge the gap' still remains a dream (were there at least some attempts to initiate anything of the kind?), bearing in mind the considerable increase in the number of books for children, it would have been a useful step to assist in delivering those books to remote provincial schools, - in other words, to help with their distribution. However, Mr. Dipak Shah, a shop assistant at Bookpoint, confirms that "books that go to rural areas are mostly supplied by the publishing houses themselves", - which means that centralized system of distribution is still lacking.

Odaga's advice to the universities to "establish a literary association... [which] could do much through encouraging young and up-coming writers" has partially been fulfilled. At least, the University of Nairobi has the Literature Students Association and the Mwangaza journal for aspiring writers (maybe other universities have something of the kind). However, any sort of specialized project for the writers, illustrators and publishers of children's books still remains a desire for the future (it seems worth noticing that such projects exist in Tanzania and Uganda, in spite of weaker economic conditions of these countries).

"Perhaps it is correct to suppose that the reading habits of children and the youth are influenced greatly by their teachers", writes Asenath Odaga in her book. We 
cannot therefore talk of children and young people's literature and fail to examine critically the part teachers and school situations play in the reading habits of the children. Therefore, teachers should, first and foremost, be actively involved in order to make any meaningful changes in schools" (68).

Were these 'meaningful changes' made? According to all the young mothers interviewed, compared to Western literature, their children find local literature very boring. The mothers think that there is nothing being done to try and capture the children's attention. "African books are just not as interesting", they say. They all try to instil their culture in their children via songs, and also try to make frequent visits to relatives in their home towns. These mothers say that children would only read African literature if it is prescribed in their school syllabi. When asked whether schools are making any effort in educating children about African literature, these mothers replied in unison: "Not at all!"

Currently the question is not only to get proper books - they are there (although the readers need more) - but to make a proper selection, to organize the syllabus correctly. Most probably, I argue, 14-year-olds will be bored by Things Fall Apart - merely because this book does not correspond to their age, they will not understand it fully. Moreover, in many primary schools children are not given any African books to read (apart from some samples of oral literature). Again the voice of Asenath Bole Odaga:

There is a strong allegation made to the effect that Africans never read books of any nature at all after they leave formal schooling, especially, this is said of fiction. It could be the allegation bears some truth, and if at all it does, then the explanation must lie in the fact that the literature that most of these people read while they were young and in school, was geared mainly towards passing examinations (69-70).

I have only one illustration to this: the results of a survey conducted among fifty recent school leavers in Nairobi. When asked 'Which books by African authors have you read in the last three years?' the school leavers (with some very few exceptions) only mentioned the set books: Achebe's novels (Man of the People - 19 students, Things Fall Apart - 12 students), followed by Margaret Ogola's The River and the Source (5 students) and Francis Imbuga's Aminata ( 5 students). The total list of titles mentioned included 32 books.

The results of this survey reflect the general situation in the country. The school system -which is supposed to develop children's reading habits - does not do that. In case a school leaver manages to pursue higher studies it is invariably too late to cultivate a reading culture for enjoyment and intellectual development. 


\section{Conclusion}

But all is not lost. In fact, it could be said that things are not bad at all, and the positive change is ever increasing. As Mr. Dipak Shah observed in the interview, "the largest appeal for Kenyan children's books has been during the last four years, and it is still on the increase. It could have been spurred by the new syllabus". Considerable changes and achievements were made compared to the state which was described in the above-quoted book by Asenath Bole Odaga. But the final passage of the conclusion chapter of her study remains, in my opinion, as relevant and urgent today as when it was written for the first time:

We need people who find pleasure in the venture to advance and promote literature as a whole; to make Kenyans youth proud of their heritage, culture and aesthetic values. It is further hoped that this study will succeed in conveying the message to all those Kenyans who are directly or indirectly involved with the subject and will inspire more interest in production and research on local literature. As we have already seen, a number of African scholars and writers have made some attempts to give the correct picture of the African world. But there is still a great need for many more to take up writing of literature for Kenyans (72).

\section{References}

Douglas Killam \& Ruth Rowe (ed), (2000). Companion to African Literatures. London: James Currey.

Wa Mberia, Kithaka (2003). "Kiswahili and Other Indigenous Kenyan Languages in the Performing Arts" in Nairobi Journal of Literature, Vol. 1: 61-69

Odaga, Asenath Bole (1985). Literature for Children and Young People in Kenya. Nairobi: Kenya Literature Bureau. 